\author{
Marta Kowalczuk-Walędziak \\ Uniwersytet w Białymstoku \\ E-MAIL: m.kowalczuk@uwb.edu.pl
}

\title{
Kilka uwag o (roz)łączności działalności badawczej i dydaktycznej nauczyciela akademickiego
}

\begin{abstract}
STRESZCZENIE
Przedmiotem analiz w tym tekście jest relacja między działalnością badawczą i dydaktyczną nauczyciela akademickiego. Celem zaś jest ukazanie, w świetle dostępnej literatury przedmiotu, różnych aspektów (odrębności i związków) działalności badawczej i dydaktycznej nauczyciela akademickiego, a także korzyści wynikających z łączenia obu tych obszarów. Zaprezentowano także model powiązań między badaniami naukowymi i działalnością dydaktyczną w programach kształcenia akademickiego w ujęciu M. Healeya. W podsumowaniu zwrócono uwagę na potrzebę podejmowania prób badawczych i praktycznych zastosowań koncepcji łączenia badań naukowych i działalności dydaktycznej w polskim szkolnictwie wyższym.

sŁoWA KLUCzOWE: kształcenie, badania, nauczyciel akademicki, relacja między badaniami i kształceniem
\end{abstract}

\section{Wprowadzenie}

Dokonując rozważań na temat związków działalności badawczej i dydaktycznej nauczyciela akademickiego, w pierwszej kolejności trzeba skierować uwagę w stronę humboldtowskiej koncepcji uniwersytetu, czyniącej jedność badań i nauczania fundamentem kształcenia uniwersyteckiego. Jedność ta wyznaczała profesorom-nauczycielom akademickim, jak i studentom, konieczność wspólnego uczestnictwa w procesie badawczym, poszukiwania prawdy i dochodzenia do wiedzy (Sajdak, 2013). Anna Sajdak (2013, s. 109) wskazuje, że „[k]onsekwencje takiego ustawienia realizacji zadań kształcenia w uniwersytecie widoczne są do dziś, przede wszystkim w opisie funkcji i zadań zawodowych nauczyciela akademickiego, $\mathrm{w}$ obecnym wciąż promowaniu relacji mistrz - uczeń jako podstawowego modelu kształcenia czy wreszcie w układzie kryteriów oceny pracownika uniwersytetu oraz warunków jego zawodowego awansu". Od lat 70. XX wieku relacja między badaniami naukowymi a kształceniem w pracy nauczyciela akademickiego oraz jej znaczenie dla doskonalenia skuteczności działań podejmowanych w procesie kształcenia stała się przedmiotem licznych dyskusji naukowych i intensywnych badań empirycznych 
prowadzonych w wielu krajach Europy i świata (przegląd tychże np. Tight, 2016; Elken i Wollscheid, 2016). Badania te obejmują m.in. istotę, rodzaje, odrębności i związki między działalnością naukową i dydaktyczną nauczyciela akademickiego, ich uwarunkowania, efekty dla uczestników procesu kształcenia (nauczycieli akademickich i studentów) i instytucji uniwersytetu, strategie implementacji w praktyce kształcenia akademickiego, i uwzględniają odmienne perspektywy poznawcze i badawcze.

Celem tego artykułu jest ukazanie, w świetle dostępnej literatury przedmiotu, specyfiki relacji pomiędzy działalnością badawczą i dydaktyczną nauczyciela akademickiego, korzyści wynikających z łączenia tych obszarów oraz przedstawienie modelu wiązania badań naukowych i działalności dydaktycznej w programach kształcenia akademickiego w ujęciu Micka Healeya. Jednakże chcę od razu wskazać, że opracowanie to nie zawiera systematycznego przeglądu literatury na ten temat, lecz jest próbą wprowadzenia Czytelnika w problematykę zawartą w tytule.

Poddany analizie problem relacji między pracą naukowo-badawczą i dydaktyczną nauczyciela akademickiego ma co najmniej dwojakie uzasadnienie.

Po pierwsze, namysł nad tym problemem wydaje się szczególnie istotny $\mathrm{w}$ dzisiejszych czasach, kiedy to instytucja uniwersytetu (oraz profesja nauczyciela akademickiego) w wielu krajach świata (w tym w Polsce) znajduje się w obliczu wyzwań będących następstwem różnorodnych przeobrażeń społecznych, ekonomicznych czy edukacyjnych (np. Czerepaniak-Walczak, 2013; European Commission/EACEA/Eurydice, 2017; Kwiek, 2015; Malewski 1998; Teichler, Arimoto i Cummings, 2013), które - jak sygnalizują badacze - mogą determinować także charakter związków między działalnością badawczą i dydaktyczną (np. Kwiek, 2015; Leister, Enders i de Boer, 2009; Mägi i Beerkens, 2016). Mägi i Beerkens (2016) zauważają, że - z jednej strony - rozwój społeczeństwa wiedzy sprzyja zacieśnianiu relacji między działalnością badawczą i dydaktyczną, z drugiej zaś - globalizacja, ideologia rynkowa, postępująca komercjalizacja wiedzy czy umasowienie kształcenia zdają się raczej rozdzielać (przeciwstawiać) te dwa obszary działalności nauczyciela akademickiego. Autorki jako przykład podają globalną rywalizację między uniwersytetami, wyrażoną w postaci różnorodnych rankingów, w których pozycja uniwersytetu jest uzależniona przede wszystkim od oceny działalności (doskonałości) badawczej (Mägi i Beerkens, 2016). Warto tu wspomnieć także o propozycjach różnicowania typów uniwersytetu na badawcze, badawczo-dydaktyczne czy dydaktyczne, różnicowania stanowisk oferowanych nauczycielom akademickim, przyznających priorytet bądź pracy naukowo-badawczej, bądź pracy dydaktycznej, czy kryteriach okre- 
sowej oceny osiągnięć nauczyciela akademickiego. Również sami nauczyciele akademiccy (głównie z niewielkim stażem pracy w uczelni) zgłaszają trudności w zachowaniu równowagi (jedności) między prowadzonymi badaniami a działalnością dydaktyczną (np. Kowzan i in., 2015; Kwiek, 2015).

Po drugie, $\mathrm{w}$ ostatnich latach $\mathrm{w}$ polskim dyskursie naukowym można zauważyć pewien niedosyt badań empirycznych dotyczących relacji pomiędzy działalnością badawczą i dydaktyczną nauczyciela akademickiego i jej znaczenia dla uzyskiwanych efektów w procesie akademickiego kształcenia studentów. Znakomite wykładnie powinności i ról nauczycieli akademickich, akcentujące konieczność łączenia pracy naukowej z działalnością dydaktyczną, zawarte w pracach Sergiusza Hessena (1995), Floriana Znanieckiego (1984) czy Janusza Goćkowskiego (1998), nie stały się w późniejszych latach przedmiotem szeroko zakrojonych badań empirycznych. Nie oznacza to jednak, że problematyka ta jest całkowicie marginalizowana $\mathrm{w}$ krajowej literaturze przedmiotu. Pewne aspekty tego zagadnienia są uwzględniane na marginesie większych badań empirycznych lub teoretycznych nad procesem kształcenia w uniwersytecie czy też rozważań o zadaniach, kompetencjach oraz warunkach oceny nauczyciela akademickiego (np. Bauman, 2011; Bolałek, 2015; Brzeziński, 1995; Ciekot, 2005; Denek, 2009; Jaskot i Jazukiewicz, 2006; Napiecek, 2015; Marszałek i Pasikowski, 2014; Sajdak, 2013; Szczepański, 1983; Wach-Kąkolewicz, 2017, Zając, 2012). Podobnie w polskich dokumentach dotyczących diagnozy, rozwoju i kierunku zmian w szkolnictwie wyższym ich autorzy tylko wspominają o idei łączenia kształcenia i badań w uniwersytecie (np. Górniak, 2015), bez wskazywania kierunków rozwiązań w tym zakresie. Ten tekst, zawierający analizę teorii, poglądów i opinii głównie badaczy zagranicznych, może, w moim przekonaniu, nieco wypełnić ową lukę, a przede wszystkim stanowić przyczynek do kontynuowania dyskusji i badań w kontekście polskiego szkolnictwa wyższego.

Przeprowadzając analizę $\mathrm{w}$ kolejnych częściach tego tekstu, najpierw dokonuję wyjaśnień terminologicznych, wskazując na różne aspekty odrębności i związków działalności badawczej i dydaktycznej nauczyciela akademickiego, dalej przedstawiam korzyści wynikające z łączenia obu obszarów, prezentuję model powiązań między badaniami naukowymi i kształceniem w ujęciu Micka Healeya, po czym podsumowuję rozważania.

Zanim jednak przejdę do głównego wątku rozważań, chcę zwrócić uwagę na jeszcze jedną sprawę. Badacze zagadnienia wskazują, że łączenie działalności badawczej i dydaktycznej nauczyciela jest warunkowane wieloma czynnikami, m.in. osobowościowymi, organizacyjnymi, instytucjonalnymi czy specyfiką uprawianej dyscypliny naukowej (przegląd tychże np. Elken 
i Wollscheid, 2016). Przy czym szczególne znaczenie w grupie tych czynników jest przydawane specyfice badań prowadzonych w różnych dyscyplinach nauki (Jenkins, Healey i Zetter, 2007). Rzecz dotyczy zarówno specyfiki badań prowadzonych w danej dyscyplinie w ogóle (np. badania podstawowe, aplikacyjne itd.), jak i sposobów konceptualizacji przez nauczycieli akademickich działalności badawczej (Brew, 2001). Chociaż te uwarunkowania nie stanowią przedmiotu podjętych tu analiz, to jednak wyznaczają potrzebę doprecyzowania w tym tekście terminu „badania”. Przyjmuję, że badania to świadomy i celowy proces zróżnicowanych działań służących gromadzeniu, analizowaniu i interpretowaniu danych niezbędnych do rozwiązywania problemów w danej dyscyplinie naukowej. Takie szerokie ujmowanie tego terminu, wyznaczające rozległe pole poznania i refleksji, ma duże znaczenie dla oglądu związków między badaniami naukowymi i pracą dydaktyczną nauczyciela akademickiego (Elken i Wollscheid, 2016).

\section{Lączenie działalności badawczej i dydaktycznej w pracy nauczyciela akademickiego - różnorodność ujęć, znaczeń i poglądów}

Jak wspominałam, łączenie działalności badawczej i dydaktycznej w pracy nauczyciela akademickiego stanowi przedmiot licznych dyskusji i intensywnych badań empirycznych. Jednakże - jak sygnalizują niektórzy autorzy (np. Malcolm, 2014; Trowler i Warehan, 2007) - wciąż istnieje wiele kontrowersji, niejasności i rozbieżności w tym obszarze. Przede wszystkim zwraca uwagę brak jednomyślności w definiowaniu tego zjawiska. W anglojęzycznej literaturze przedmiotu funkcjonuje wiele określeń: interaction, intercorrelation, nexus, integration, relationship, impact, link, linkage, co przekładając na język polski oznacza powiązanie, związek, relację, splot, integrację, oddziaływanie, sprzężenie między badaniami i kształceniem lub odwrotnie (Elken i Wollscheid, 2016; Tight, 2016; Trowler i Warehan, 2007). Jednakże, co podkreśla Malcolm Tight (2016), istnieje także wiele publikacji, w których autorzy posługują się szerokim terminem „badania i kształcenie” bez wyraźnego wskazywania na relacje między nimi.

Simons i Elen (2007) wskazują na jeszcze inną ambiwalencję (dwuznaczność) terminologiczną związaną ze stosowaniem zamiennie pojęć research-teaching nexus („łączenie działalności badawczej i dydaktycznej”) i education through research („kształcenie przez badania”). Ta ambiwalencja, jak zauważają autorzy, wynika $\mathrm{z}$ funkcjonowania dwóch odmiennych podejść do badań w edukacji akademickiej: w pierwszym uznaje się badania za narzędzie w środowisku uczenia się $\mathrm{w}$ celu rozwijania kompetencji wymaganych przez społeczeństwo wiedzy, w drugim zaś są one ujmowane jako proces gro- 
madzenia i rozwoju wiedzy, a edukacja akademicka jest postrzegana przez pryzmat udziału studentów w badaniach (Simons i Elen, 2007).

Z kolei Trowler i Warehan (2007), na podstawie przeglądu różnych koncepcji łączenia badań naukowych i kształcenia w uczelniach, podkreślają, że jest ono postrzegane także jako włączanie rezultatów badań naukowych do programów kształcenia studentów, angażowanie studentów w badania własne i/lub realizowane przez pracowników naukowych uczelni, prowadzenie badań przez nauczycieli akademickich i dzielenie się ich rezultatami ze studentami.

Ta różnorodność terminologiczna poniekąd odzwierciedla także poglądy badaczy na temat (możliwych) relacji pomiędzy działalnością badawczą i dydaktyczną. Elken i Wollscheid (2016) zauważają, że na przykład zwolennicy symbiozy/integracji tych dwóch obszarów znacznie częściej w swoich pracach używają terminu nexus'. Jednakże, zdaniem tych autorek, to sygnalizuje zdecydowanie głębsze „podziały” między badaczami co do zależności między działalnością badawczą i dydaktyczną nauczyciela akademickiego. Dość duża część badaczy argumentuje, że między pracą naukowo-badawczą i dydaktyką istnieją silne związki (np. Brew, 2006; szerszy przegląd w: Elken i Wollscheid, 2016; Tight, 2016); inni wyrażają zaś pogląd, że występowanie (lub nie) tych związków jest uzależnione od specyfiki dyscyplin naukowych i rodzajów badań $w$ nich prowadzonych (Barnett, 2005). Są też badacze, którzy w oparciu o metaanalizy istniejących wyników badań na ten temat wskazują na odrębności pracy naukowej i dydaktycznej (np. Hattie i Marsh, 1996). Warto w tym miejscu dodać, że te odmienne stanowiska badaczy są powiązane z różnymi sposobami ujmowania (konceptualizacji) relacji między badaniami i kształceniem, a tym samym innymi sposobami jej badania (Stappenbelt, 2013). Można tu wyróżnić dwa podstawowe nurty:

1) Wyniki badań ilościowych, skoncentrowanych przede wszystkim na poszukiwaniu zależności pomiędzy efektywnością kształcenia, mierzoną ocenami studentów, i produktywnością badawczą nauczycieli, mierzoną głównie liczbą publikacji naukowych, wskazują na istnienie niewielkiej lub na brak zależności między badaniami i kształceniem (np. Hattie i Marsh, 1996; Kwiek, 2015). Istnieją także dowody, że za-

Angielski termin nexus trudno jednoznacznie przetłumaczyć na język polski. W słownikach można odnaleźć takie (alternatywne) jego tłumaczenia, jak: sieć, ogniwo, związek, powiązanie. Malcolm Tight (2016, s. 294) wskazuje, że dla zwolenników symbiozy badań i kształcenia w uniwersytecie termin nexus oznacza coś więcej niż prosty związek między nimi. A zatem można wnioskować, że jest to pewien rodzaj powiązań sieciowych, złożonych relacji i oddziaływań, wzajemnego „przenikania” tych dwóch obszarów. 
angażowanie nauczyciela akademickiego $\mathrm{w}$ działalność dydaktyczną zmniejsza jego produktywność badawczą (Ramsden i Moses, 1992).

2) Natomiast wyniki badań jakościowych, koncentrujących się głównie na opiniach i doświadczeniach nauczycieli akademickich, najczęściej wskazują na ich silne przekonanie o potrzebie wzmacniania związku pomiędzy badaniami i dydaktyką, uzasadniane wieloma korzyściami dla studentów (np. Jensen, 1988; Visser-Wijnveen i in., 2012). Inaczej rzecz ujmując, większość badanych nauczycieli akademickich przyznaje, że aby być „dobrym” dydaktykiem, trzeba być równocześnie „dobrym" badaczem.

Ukazane wyżej odmienności w stanowiskach badaczy nie wyczerpują złożoności zagadnienia. Interesujące w tym kontekście są wyniki badań Coate, Barnett, Williams i in. (2001) (za: Tight, 2016), które wskazują na występowanie jeszcze szerszego spektrum zależności między prowadzeniem badań i nauczaniem, obejmującego następujące ich typy: (i) integracja, (ii) działalność badawcza jako czynnik pozytywnie oddziaływający na kształcenie, (iii) kształcenie jako czynnik pozytywnie oddziaływający na pracę badawczą, (iv) odrębne działania o niewielkim wzajemnym oddziaływaniu, (v) działalność badawcza jako czynnik negatywnie oddziaływający na kształcenie, (vi) kształcenie jako czynnik negatywnie oddziaływający na pracę badawczą.

Z przedstawionych rozważań wynika, że specyfika relacji między działalnością badawczą i dydaktyczną nauczyciela jest złożona. Dostępne wyniki badań wskazują bowiem na różne rodzaje tych relacji (połączenie istnieje lub nie) oraz ich znak (relacje pozytywne lub negatywne). Chociaż istnieją różnice $\mathrm{w}$ stanowiskach badaczy co do tej kwestii, to jednak dominującym w literaturze przedmiotu jest pogląd, że działalność badawcza i dydaktyczna nauczyciela akademickiego mogą i powinny być wzajemnie się warunkującymi i pobudzającymi sferami. Innymi słowy, sygnalizowane różnice stanowisk badaczy czy odmienne wyniki badań nie powinny kwestionować wysiłku i korzyści wynikających z wiązania badań i kształcenia w edukacji akademickiej. Niektórzy autorzy wskazują, że należy je ujmować w kategoriach wątpliwości, które wymagają szczególnie pogłębionego namysłu i dalszych badań (Malcolm, 2014). Taką orientację przyjmuję i zgodnie z tą orientacją dokonuję dalszych analiz.

\section{Zalety (korzyści) łączenia przez nauczyciela prowadzonych badań z działalnością dydaktyczną}

Rozpoczynając rozważania na ten temat, chcę w pierwszej kolejności zwrócić uwagę na (nieprzypadkowe) ujęcie tytułu tej części tekstu. Sygnalizuje ono 
bowiem, że rzecz dotyczy oddziaływania działalności badawczej na pracę dydaktyczną. Rzeczywiście, zdecydowana większość badań dotyczy oddziaływania działalności badawczej nauczyciela na jego pracę dydaktyczną. Znacznie rzadziej podejmowane są próby badawcze w zakresie określenia znaczenia działalności dydaktycznej dla pracy naukowo-badawczej (Stappenbelt, 2013).

Marsh i Hattie (2002) wskazują, że nauczyciele akademiccy, którzy są aktywnymi badaczami, mogą wykorzystywać wyniki swoich badań do wzbogacania i aktualizacji materiału wykładanego dla studentów. Ponadto są oni bardziej skuteczni w rozwijaniu u studentów rozumienia złożonych faktów niż biernej ich akceptacji. Prezentowanie wyników badań własnych podczas zajęć ze studentami wzmacnia również autentyczność wykładanych treści (Marsh i Hattie, 2002). Cytowani autorzy wskazują także na korzystne oddziaływanie pracy dydaktycznej na działalność badawczą nauczyciela. Ich zdaniem dzielenie się wynikami badań własnych ze studentami może pomóc badaczom $\mathrm{w}$ zrozumieniu niektórych kwestii. Natomiast zgłaszane przez studentów sugestie, komentarze, pytania czy uwagi mogą stanowić z jednej strony - potwierdzenie przyjętych założeń badawczych, z drugiej zaś - źródło inspiracji dla kolejnych badań (Marsh i Hattie, 2002).

Podobne stanowisko wyrażają inni badacze, podkreślając szczególną wartość łączenia tych dwóch obszarów działalności nauczyciela akademickiego dla przebiegu i doskonalenia skuteczności działań podejmowanych w procesie kształcenia i uzyskiwanych efektów. Na przykład wyniki badań przeprowadzonych przez Mägi i Beerkens (2016) wskazują, że nauczyciele akademiccy będący równocześnie aktywnymi badaczami są bardziej skłonni do stosowania strategii kształcenia opartych na badaniach, takich jak: angażowanie studentów w grupy badawcze, publikowanie artykułów naukowych ze studentami i wykorzystywanie informacji pochodzących z badań własnych czy zdobytych w toku konferencji w toku pracy dydaktycznej. Wyniki innych badań (np. Healey, 2005; Jenkins, 2004) wskazują, że nauczyciele akademiccy dostrzegają następujące walory wiązania pracy badawczej z dydaktyczną: wzmocnienie u studentów motywacji do uczenia się, większą satysfakcję z uczestnictwa w zajęciach i lepsze wyniki w uczeniu się. Warto w tym kontekście wyeksponować wyniki polskich badań na ten temat, przeprowadzonych przez Teresę Bauman (2011). Autorka, dokonując oceny procesu kształcenia w uniwersytecie, zapytała nauczycieli akademickich o ich opinie na temat relacji pomiędzy pracą naukową a dydaktyczną. Niemal trzy czwarte respondentów przyznało, że prowadzenie badań naukowych ułatwia pracę dydaktyczną, podając takie argumenty, jak: praca naukowa pogłębia 
wiedzę nauczyciela, stanowi źródło dobrych przykładów, wyniki badań własnych stanowią praktyczną egzemplifikację wiedzy teoretycznej, przez co studenci lepiej rozumieją omawiane zagadnienia, bycie badaczem zwiększa pewność siebie nauczyciela akademickiego, zagadnienia będące przedmiotem badań własnych można uczynić tematem samodzielnego kursu (Bauman, 2011, s. 131-132).

Wyniki różnych badań prowadzonych w grupach studentów zdają się potwierdzać wyżej przedstawione korzyści. Studenci wskazują przede wszystkim na zwiększenie motywacji do uczestnictwa w danych zajęciach, większy entuzjazm i wiarygodność u nauczycieli przy prezentowaniu różnych zagadnień, uatrakcyjnienie zajęć i czynienie ich bardziej stymulującymi intelektualnie. Ponadto doceniają także uczestnictwo w badaniach prowadzonych na uczelni ze względu na możliwość bliskiej współpracy z nauczycielami akademickimi, bycia częścią społeczności naukowej wydziału (Neumann, 1994; Robertson i Blackler, 2006 za: Visser-Wijnveen i in., 2016; Stappenbelt, 2013).

Skoro łączenie działalności badawczej z dydaktyczną przez nauczyciela akademickiego jest korzystne z punktu widzenia procesu kształcenia studentów, to trudno się nie zgodzić, że przyjmowanie przez nauczycieli określonych wzorców (modeli) tego wiązania jest zjawiskiem pożądanym. W literaturze przedmiotu istnieje dość duża różnorodność w zakresie tych modeli². Ze względu na ograniczone ramy opracowania swoją uwagę skupiam tu tylko na koncepcji Micka Healeya, która - jak wskazują Elken i Wollscheid (2016) - jest najczęściej cytowana i poddawana empirycznym weryfikacjom.

\section{Model łączenia badań naukowych i działalności dydaktycznej w ujęciu Micka Healeya}

Healey (2005), wykorzystując założenia koncepcji Rona Griffithsa (2004), wyodrębnił 4 sposoby łączenia badań naukowych i działalności dydaktycznej w programach akademickiego kształcenia, biorąc pod uwagę: a) ukierunkowanie programu kształcenia na przekaz wyników badań (research content) bądź na proces prowadzenia badań (research process) oraz b) aktywność studentów - studenci jako bierni odbiorcy wyników badań (students audience) lub studenci jako twórcy wyników badań (students participants). Według M. Healeya (2005; także Healey i Jenkins, 2006) programy kształcenia mogą być:

Więcej na ten temat w: Kowalczuk-Walędziak, M. (2017). Komplementarność badań i kształcenia w edukacji akademickiej nauczycieli. W: J. Madalińska-Michalak (red.), O nowa jakość edukacji nauczycieli. Warszawa: Wydawnictwo UW. 
- research-led ${ }^{3}$ - studenci poznają wyniki badań prowadzonych w dyscyplinie ich studiów; programy kształcenia są dostosowane do profilu badań prowadzonych na danym wydziale,

- research-oriented - studenci zdobywają wiedzę o elementach procesu badawczego, w programach kształcenia zwraca się uwagę nie tylko na przekaz wiedzy, ale i sposoby jej osiągania,

- research-based - programy kształcenia są konstruowane wokół aktywności, które umożliwiają i wspierają samodzielność poznawczą i badawczą, samorefleksję, samoświadomość i autokreację u studentów,

- research-tutored - działalność studentów jest oparta na analizie i syntezie wyników badań i skoncentrowana na przygotowywaniu prac pisemnych, pracy dyplomowej oraz licznych dyskusjach z nauczycielami akademickimi, głównie w toku seminariów.

Rzecz można ująć w formie następującego schematu:

Students participants

Studenci jako uczestnicy badań

\section{Research-tutored}

- działalność studentów jest oparta na analizie i syntezie wyników badań i skoncentrowana na przygotowywaniu prac pisemnych, pracy dyplomowej oraz licznych dyskusjach z nauczycielami akademickimi

Ukierunkowanie na treści badań

\section{Research-led}

- studenci poznają wyniki badań prowadzonych w dyscyplinie ich studiów,

- programy kształcenia są dostosowane do profilu badań prowadzonych na danym wydziale
Research-based

- programy kształcenia są konstruowane wokół aktywności, które umożliwiają i wspierają samodzielność poznawczą i badawczą, samorefleksję, samoświadomość i autokreację u studentów

Ukierunkowanie na proces badań

\section{Research-oriented}

- studenci zdobywają wiedzę

o elementach procesu badawczego,

- w programach kształcenia

zwraca się uwagę nie tylko na przekaz wiedzy, ale i sposoby

jej osiągania

Students audience Studenci jako odbiorcy wyników badań

\section{Schemat: Model łączenia działalności badawczej z kształceniem w ujęciu M. Healeya (2005, s. 70)}

Przedstawione wyżej sposoby łączenia działalności dydaktycznej i badawczej w programach akademickiego kształcenia studentów wzmacniają pozy-

3 Ze względu na trudności w jednoznacznym przekładzie nazw tych sposobów z języka angielskiego na język polski, zdecydowałam się pozostawić je w oryginalnym brzmieniu. 
tywne rezultaty $\mathrm{w}$ ich uczeniu się, jednakże - co podkreślają Healey i Jenkins (2006) - szczególne znaczenie dla osiąganych rezultatów mają sposoby wzmacniające aktywność i samodzielność badawczą studentów w procesie kształcenia.

\section{Podsumowanie}

W przedstawionym tekście dokonałam próby przybliżenia specyfiki relacji między działalnością badawczą i dydaktyczną nauczyciela akademickiego, korzyści wynikających z łączenia tych dwóch obszarów oraz możliwych sposobów ich wiązania, przede wszystkim w świetle teorii, koncepcji i poglądów zawartych w anglojęzycznej literaturze przedmiotu. Biorąc pod uwagę, że większość uniwersytetów w Polsce doświadcza problemów podobnych do tych w uniwersytetach w innych krajach Europy i świata, to wnioski płynące z tych rozważań można przenieść także na grunt uczelni polskich. Ich wartość poznawcza i praktyczna nabiera znaczenia zwłaszcza w aktualnej sytuacji szkolnictwa wyższego w Polsce, ulega bowiem ono kolejnym próbom reformowania, dyskutowane są różne zmiany w zakresie wypełniania przez uniwersytet funkcji badawczej oraz dydaktycznej, co pośrednio oddziaływać może na kształt relacji między pracą dydaktyczną i badawczą nauczyciela.

Podzielam stanowisko wielu badaczy przywołanych w tym tekście, iż łączenie badań i dydaktyki w pracy nauczyciela akademickiego ma dużą wartość dla doskonalenia skuteczności jego działań podejmowanych w procesie kształcenia studentów i uzyskiwanych efektów. W związku $\mathrm{z}$ tym niezbędne wydaje się tworzenie warunków sprzyjających zacieśnianiu związków między działalnością badawczą i dydaktyczną w polskich uniwersytetach. Pewnym utrudnieniem mogą być tutaj nieliczne doświadczenia praktyczne i badania empiryczne. Ponadto może to wymagać od nauczycieli akademickich dodatkowej wiedzy i umiejętności, a także pogłębionej refleksji nad własną pracą, przebiegiem procesu kształcenia i jego rezultatami. Ważne jest także większe wsparcie decydentów politycznych czy władz uczelni w dążeniu przez nauczycieli akademickich do łączenia obu obszarów w ich pracy zawodowej. Potrzeba także czynić więcej poszukiwań teoretycznych w tym zakresie, podejmować badania diagnostyczne i wyjaśniające istniejące strategie wiązania działalności dydaktycznej i badawczej w polskich uczelniach, dokonywać analizy i weryfikacji praktyk stosowanych w szkolnictwie wyższym w innych krajach i próbować, te najbardziej adekwatne, aplikować w polskiej praktyce edukacyjnej. 


\section{BIBLIOGRAFIA}

Bauman, T. (2011). Proces kształcenia w uniwersytecie w perspektywie potrzeb, oczekiwań i ocen nauczycieli akademickich oraz studentów. Raport z badań. Gdańsk: Fundacja Rozwoju Uniwersytetu Gdańskiego.

Bolałek, J. (2015). Kształcenie oparte na badaniach (Research Based Education/Learning). W: J. Bolałek, E. Szymczak, T. Sadoń-Osowiecka (red.). Dobre zwyczaje akademickie w naukach przyrodniczych (s. 21-29). Kraków: LIBRON. Pozyskano z: https://oig.ug.edu.pl/sites/default/files/_nodes/news/46983/files/dobre_zwyczaje_akademickie.pdf, (data dostępu: 10.12.2017).

Brew, A. (2001). Conceptions of research: a phenomenographic study. Studies in Higher Education, 26 (3), 271-285.

Brew, A. (2006). Research and teaching: beyond the divide. Basingstoke: Palgrave Macmillan.

Brzeziński, J. (1995). Autorytet profesora uniwersytetu w świetle tezy o jedności kontekstu badania i kontekstu nauczania. Nauka, 4.

Ciekot, K. (2005). Udział studentów w badaniach realizowanych przez nauczycieli akademickich jako przyczynek do samopoznania. Pedagogika Szkoły Wyższej, 26/27, 199-209.

Czerepaniak-Walczak, M. (red.). (2013). Fabryki dyplomów czy universitas? O „nadwiślańskiej” wersji przemian w edukacji akademickiej. Kraków: Oficyna Wydawnicza „Impuls”.

Denek, K. (2009). Podstawowe powinności nauczycieli akademickich. W: A. J. Sowiński (red.), Kultura akademicka w ogladzie pedagogicznym. Szczecin: na zlec. Ogólnopolskiego Seminarium Pedagogiki Szkoły Wyższej: Ars Atelier.

Elken, M., Wollscheid, S. (2016). The relationship between research and education: typologies and indicators. A literature review. Technical report. Nordic Institute for Studies in Innovation, Research and Education (NIFU). Pozyskano z: https://brage.bibsys.no/xmlui/handle/1125o/2386141, (data dostępu: 10.12.2017).

European Commission/EACEA/Eurydice. (2017). Modernisation of higher education in Europe: academic staff - 2017. Eurydice report. Luxembourg: Publications Office of the European Union. Pozyskano z: https://webgate.ec.europa.eu/fpfis/mwikis/eurydice/images/3/ 3C/209_Academic_Staff_2017.pdf, (data dostępu: 10.12.2017).

Goćkowski, J. (1998). Funkcjonalność uniwersytetu w perspektywie długiego trwania. W: H. Żytkowicz (red.), Idea uniwersytetu u schyłku tysiąclecia. Warszawa: Wydawnictwo Naukowe „Scholar”.

Górniak, J. (red.). (2015). Diagnoza szkolnictwa wyższego. Cz. III. Pozyskano z: https://www. frp.org.pl/images/publikacje/publication/cz_iii_program_o01244_diagnoza.pdf, (data dostępu: 10.12.2017).

Hattie, J., Marsh, H. W. (1996). The relationship between research and teaching: A meta-analysis. Review of Educational Research, 66 (4), 507-542.

Healey, M. (2005). Linking research and teaching: exploring disciplinary spaces and the role of inquiry-based learning. W: R. Barnett (red.), Reshaping the university: new relationships between research, scholarship and teaching (s. 67-78). McGraw Hill: Open University Press. Pozyskano z: http://citeseerx.ist.psu.edu/viewdoc/download?doi=10.1.1.465.7761\&rep=rep1 \&type=pdf, (data dostępu: 10.12.2017).

Healey, M., Jenkins, A. (2006). Strengthening the teaching-research linkage in undergraduate courses and programs. New Directions for Teaching and Learning, 107, 45-55.

Hessen, S. (1995). Podstawy pedagogiki. Warszawa: Wydawnictwo Akademickie „Żak”.

Jaskot, K., Jazukiewicz, J. (2006). Role zawodowe nauczyciela akademickiego. W: J. Jaskot (red.), Wprowadzenie do pedagogiki szkoły wyższej. Szczecin: Oficyna INplus.

Jenkins, A. (2004). A guide to the research evidence on teaching-research relationships. York: Higher Education Academy.

Jenkins, A., Healey, M., Zetter, R. (2007). Linking teaching and research in disciplines and departments. York: Higher Education Academy. Pozyskano z: https://www.heacademy. 
ac.uk/knowledge-hub/linking-teaching-and-research-disciplines-and-departments, (data dostępu: 10.12.2017).

Jensen, J. (1988). Research and teaching in the universities of Denmark: does such an interplay really exist? Higher Education, 17 (1), 17-26.

Kowalczuk-Walędziak, M. (2017). Komplementarność badań i kształcenia w edukacji akademickiej nauczycieli. W: J. Madalińska-Michalak (red.), O nowa jakość edukacji nauczycieli. Warszawa: Wydawnictwo UW.

Kowzan, P., Zielińska, M., Kleina-Gwizdała, A., Prusinowska, M. (2015). „Nie zostaje mi czasu na pracę naukową". Warunki pracy osób ze stopniem doktora, zatrudnionych na polskich uczelniach. Raport NOU. Gdańsk, Bydgoszcz, Warszawa: Nowe Otwarcie Uniwersytetu. Pozyskano z: https://depot.ceon.pl/bitstream/handle/123456789/9225/Nie\%2Ozostaje\%2O mi\%2oczasu\%2ona\%2opracę\%2onaukową.pdf?sequence=1\&isAllowed=y, (data dostępu: 10.12.2017).

Kwiek, M. (2015). Uniwersytet $w$ dobie przemian. Instytucje i kadra akademicka $w$ warunkach rosnącej konkurencji. Warszawa: PWN.

Leister, L., Enders, J., de Boer, H. (2009). The balance between teaching and research in Dutch and English universities in the context of university governance reforms. Higher Education, 58 (5), 619-635.

Mägi, E., Beerkens, M. (2015). Linking research and teaching: are research-active staff members different teachers? Higher Education, 72 (2), 241-258.

Malcolm, M. (2014). A critical evaluation of recent progress in understanding the role of the research-teaching link in higher education. Higher Education, 67 (3), 289-301.

Malewski, M. (1998). Ewolucja uniwersytetu - implikacje dla kształcenia. Teraźniejszość - Człowiek-Edukacja, 1 (o1), 17-29.

Marsh, H. W., Hattie, J. (2002). The relation between research productivity and teaching effectiveness: complementary, antagonistic, or independent constructs? The Journal of Higher Education, 73 (5), 603-641.

Marszałek, K., Pasikowski, S. (2014). Kryteria i warunki ewaluacji nauczycieli akademickich w świetle arkuszy okresowej oceny na kierunkach pedagogicznych w polskich uniwersytetach. Rocznik Pedagogiczny, 37, 53-71.

Napiecek, R. (2015). Współzależność głównych obszarów działania uczelni wyższej. Prace Naukowe Uniwersytetu Ekonomicznego we Wrocławiu, 399, 352-360.

Sajdak, A. (2013). Paradygmaty kształcenia studentów i wspierania rozwoju nauczycieli akademickich. Kraków: Oficyna Wydawnicza „Impuls”.

Simons, M., Elen, J. (2007). The 'research-teaching nexus' and 'education through research': an exploration of ambivalences. Studies in Higher Education, 32 (5), 617-631.

Stappenbelt, B. (2013). The effectiveness of the teaching-research nexus in facilitating student learning. Engineering Education, 8 (1), 111-121.

Szczepański J. (1983). Pracownik naukowy jako nauczyciel akademicki. W: K. Denek, F. Januszkiewicz, W. Strykowski (red.), Uczelnia na miarę współczesności (s. 72-82). Poznań: Wydawnictwo Naukowe UAM.

Teichler, U., Arimoto, A., Cummings, W.K. (2013). The changing academic profession. Major findings of a comparative survey. Dordrecht, Heidelberg, New York, London: Springer.

Tight, M. (2016). Examining the research/teaching nexus. European Journal of Higher Education, 6 (4), 293-311.

Trowler, P., Wareham, T. (2007). Tribes, territories, research and teaching: enhancing the 'teaching-research' nexus. Literature review. Pozyskano z: https://www.heacademy.ac.uk/knowledge-hub/tribes-territories-research-and-teaching-enhancing-teaching-research-nexus-summary, (data dostępu: 10.12.2017).

Wach-Kąkolewicz, A. (2017). Tożsamość zawodowa nauczycieli akademickich Uniwersytetu Ekonomicznego w Poznaniu a ich kompetencje do nauczania. Studia Oeconomica Posnaniensa, 5 (3), 67-86. 
Visser-Wijnveen, G.J., van der Rijst, R.M., van Driel, J.H. (2016). A questionnaire to capture students' perceptions of research integration in their courses. Higher Education, 71 (4), 473-488.

Visser-Wijnveen, G.J., van Driel, J.H., van der Rijst, R.M., Visser, A., Verloop, N. (2012). Relating academics' ways of integrating research and teaching to their students' perceptions. Studies in Higher Education, 37 (2), 219-234.

Zając, D. (2012). Nauczyciel akademicki wobec dylematu: badacz - dydaktyk - wychowawca - organizator. Pedagogika Szkoły Wyższej, 1, 101-125.

Znaniecki, F. (1984). Społeczne role uczonych. Warszawa: PWN.

\section{SUMMARY}

\section{Commenting on the (dis)joint character of research and didactic activity of a university teacher}

The main focus of this paper is the relationship between research and teaching in higher education. Its aim is to explore different aspects of this relationship as well as benefits stemming from the connection between research and teaching in higher education through the review of relevant literature. Furthermore, Healey's research-teaching nexus model is presented. The paper concludes with suggestions for future research studies and practical applications of the idea of the research-teaching nexus in Polish higher education.

KEY WORDS: teaching, research, academic teacher, research-teaching relationship 